\title{
FOOD SAFETY REQUIREMENTS IN CASE OF SHORT FOOD SUPPLY CHAIN ${ }^{1}$
}

\author{
Kinga Nagy - Pércsi \\ associate professor \\ Faculty for Economics and Social Sciences, Szent István University \\ E-mail: nagyne.pecsi.kinga@gtk.szie.hu
}

\begin{abstract}
It can be stated according to the relevant literature that the health related characteristics of the food products and the ethical values relating to the sustainable development and consumption gains on a growing importance among the preferences of the consumers. The article introduce the different possible types of Short Food Supply Chains, the various food safety requirements relating to them and the opinion of some relevant conventional and organic farmers about the prevailing of rules. The aim of this article is to give a picture of the evolution of the food safety regulations, than a broad review of the different SFSC types, and to find the differences between the farmers' group. It investigates the most important characteristics of direct sale in the light of the recent food safety requirements among the surveyed farmers. The surveys were made as a preliminary research for a more comprehensive study.
\end{abstract}

Keywords: local food, Short Food Supply Chain, food-safety requirements, consumer preferences and trust

JEL classification: Q19, R10

LCC code: $\mathrm{S} 1$

\section{Introduction}

The most dominant recent megatrend is localization which is the opposite trend of globalization and means the growing value of every kind of locality (landscape, region, country, etc.) in contrary to the homogenization of the world markets (Petrás, 2005 in Hámori, 2013) According to the localization of the food chain the food is consumed in those countries where it is produced, so the emphasis is put on the decrease of the distance between the producers and the consumers. (Cowell-Parkinson, 2003 in Hámori, 2013) This phenomenon is related to that concept which was formulated by Tóth and Káposzta (2014) and which suggest the preference of the local resources also in the national food supply, they think it is crucial for the further development. Local food production and localized food supply chains, often referred as food relocalisation, have recently become the focus of attention among consumers (Balázs 2012, Benedek - Balázs 2014). These systems have a long tradition in the United States and in Western Europe, and they also have deep historic roots in Hungary (Balázs et al, 2015). There are two main reasons to use the origin of the product as a marketing tool (Papadopoulos - Butt, 2006 in Hámori, 2013). The companies try to find such distinctive characteristics for their products to stand the heavy competition which can be presented as an external characteristic like the place of origin, brand name and others. In parallel the costumers try to find external product characteristics which refer to the internal characteristics and can be interpreted as objective quality level indicators (Hámori, 2013). It is the specialty of the agricultural products and food that their quality is determined in a great extent by the producing circumstances and

\footnotetext{
${ }^{1}$ This work was created in commission of the National University of Public Service under the priority project KÖFOP-2.1.2-VEKOP-15-2016-00001 titled "Public Service Development Establishing Good Governance" and the Cooperative Partner/Institution
} 
conditions, the physical environment (climate, land, terrain, etc.), the cultural factors, food preparing processes, eating habits, traditions. So the place of origin as a distinctive quality indicator is a complex definition (Hámori, 2013).

It can be stated according to the relevant literature that the health related characteristics of the food products and the ethical values relating to the sustainable development and consumption gains on a growing importance among the preferences of the consumers. These processes directly or indirectly support the preference of local food products. Across the EU, a growing number of consumers choose to buy food products on local farmers' markets, directly at the farm, through basket/box delivery systems or other community-supported agriculture schemes. European customers tend to associate local products with higher quality standards (freshness, nutritional value), healthy eating, more environment-friendly production methods and a lower carbon footprint (Augère-Granier, 2016). They expect the products to be fresher, pure, healthy, natural, nutritious, better tasting and safe than their mainstream "industrial" counterparts. However it is questionable whether all of these expectations are realistic (Ter Kuile, 2012). According to a survey among the Hungarian adult population from 2014 the consumers agreed in that in the first place (they gave 4.22 points from 5) that "Recently many food products are full of hazardous materials" and in the second place (3.81) they take care of where they buy food. The statements "I keep myself to be conscious consumer", "I buy as healthy food as possible", "I always buy trustworthy food with well-known brand", "I prefer domestic products they are more trustworthy" (Jakopánecz, 2015). The abovementioned processes direct our attention to health relating aspects of local food products consumption and highlight the importance of the food safety requirements of local food production (Szilágyi-Boldizsár, 2016).

\section{Method}

In this article I would like to compare the results of two surveys relating to the food safety aspects of SFSC. One of the surveys was made among the organic farmers who sell their product direct on the organic market of Biokultúra Alliance in Budapest and controlled by the Biokontroll Ltd. A semi structured interview was made with 10 farmers in September 2017, this means that the questionnaires were filled personally during which the opinions of the respondents related to certain questions could be noted additionally and other relevant information about the way of farming could be collected. On the homepage of the Biokultúra Alliance the list of the seller of the Biokultúra Organic Market can be found but this list contains also those who are only merchandizers. According to this list there are 97 sellers on the market, but many of them only merchandizer and some of them only sell handicraft products (only folk weave for example). The applied questionnaire contained 51 questions, most of which connected to the characteristics of direct selling and the organic market. The farmers had also the opportunity to tell their opinion about the future prospects of the sector and they could introduce their development plans, intentions. As I mentioned before the way of asking questions was personal request. However it was very time consuming, this method gave opportunity for the farmers to give additional information relating to the particular questions and also to avoid misinterpretation. The other was made among the Hungarian conventional "native producers" in March of 2017.The small scale farmers stemming from different regions of Hungary. Altogether 8 case studies could be used in analysis. Two rounds of semi-structured interview was made. In the first questionnaire the general characteristics of the farms were surveyed, the questions connected to the legal status of the farm, the land property and land use, the type of production, the marketing channels and finally the socio-demographic information. On the basis of the first survey a more specialized questionnaire was compiled to the selected farmers and its questions relating to the production safety, marketing channels and the future development plans. In this case the questionnaires were filled also personally during an 
interview so the farmers had the chance to give more information to a related question. The farmers had the opportunity to tell their opinion relating to the topics in both cases. Every farmer is a licensed traditional small-scale producer and nobody is planning to change this legal status. 3 occupy with fruits and vegetable production, 3 of them keep animals, one of them occupies with honey bee keeping, and one with cereal planting on a land of 90 hectares. One of the animal keeping farms deals only with milk production.

\section{Results and discussion}

\section{Food safety requirements of the different short food supply chains}

According to the EU regulation $852 / 2004$ the safety of the food chain has to be controlled from farm to fork, each step in the food production chain taking its responsibility to deliver a safe food product to the market. The safety is to be controlled based upon the principles of 'Good Agricultural Practices' (GAP), 'Good Manufacturing Practices' (GMP) and 'Hazard Analysis and Critical Control Points' (HACCP). This regulation is valid for all food production, including the production by the short food supply chain. In Hungary from 2006 to 2010, in a series of amendments, the decree on small producers finally regulated all issues relating to small scale production, manufacturing, hygiene, trade, control, and certification. In 2006 the first regulations focused on food hygiene conditions, and in 2010, further amendments increased the quantities authorized for selling by small-scale producers and allowed them, irrespective of their place of residence, to sell products in the capital. In 2012, simplified procedures on hygiene were introduced for local farmers' markets in order to facilitate direct sales to consumers. (Kneafsey et al, 2013). For the discussion of the topic the most important definitions should be cleared. A local food system (LFS) is one in which foods are produced, processed and retailed within a defined geographical area. Examples of local food systems are: farmers markets, farmgate sales, vegetable box delivery schemes, community supported agriculture and public procurement schemes which source food from within a defined geographical radius (Kneafsey et al, 2013). Until recently, there was no common definition of short food supply chains (SFSC) at EU level, although they are broadly understood as including a minimal number of intermediaries (or even none in the case of direct sales from the producer) (AugéréGranier, 2016). Marsden et al. (2000), and later Renting et al. (2003), identify three main types of SFSC. Face-to-face: consumer purchases a product direct from the producer/processor on a face-to-face basis. Examples of face-to-face SFSCs are: farm gate sales, Pick-Your-Own, farm shops, farmers markets, roadside sales. Spatial proximity: products are produced and retailed in the specific region of production, and consumers are made aware of the 'local' nature of the product at the point of sale. In addition, this category could include specialist retailers (e.g. delicatessens, bakeries, butchers, grocers) which sell 'local' produce and also elements of the hospitality industry which sell local foods (e.g. restaurants, pubs, hotels and other accommodation). This category could also include public sector food provision, such as hospitals, schools, universities. Spatially extended: information about the place and processes of production is communicated to consumers who are outside of the region of production itself, and who may have no personal experience of that region. The main examples are PDO (Protection of Designated Origin) or PGI (Protected Geographical Indications). Different food safety requirements relating to the above mentioned categories. The "spatially extended" category is the part of the EU Quality Scheme, so tied rules should be met. There is a product description which should be taken into consideration. Only a group of producers are licensed to use the relating labels. In the case of "face-to-face" category the trust of the consumers can be the biggest, because the higher quantity of direct information. Recently, short food supply chains have been thoroughly studied in some countries; however, data are sparse from others. In Hungary, the local food movement has been developing very fast and an outburst in the 
number of farmers markets has happened, due to the changes of the legal environment as I mentioned before.

According to the survey data of Benedek et al (2014) there are different types of short supply chains in terms of farmers' profiles. The authors classified the farmers on the basis of the market type (traditional market, farmers' market or organic market) that the farmers considered as the most important for them. Their results showed that the vendors of markets are typically middleaged; organic farmers are younger and more educated. Farm size is relatively small; the smallest average size had the traditional market (TM) farmers. The authors found the motivating factors to be different in the different farmers' groups. Higher price as a motivating factor proved generally not to be the most important one in making decisions; habits and traditions have major role for TM farmers. From the aspect of the aims of this article their most interesting result was that they found the role of food processing to be the smallest among the traditional market farmers. The explanation can be for this that previously at most traditional markets it was not permitted to sell processed food due to strict food safety regulations that did not distinguish between small-scale and industrial producers. Processed food (besides the fact that the increase of selection may attract further consumers) can result in higher prices and are of importance as the main generator of income especially out of the growing season. Although the regulation has changed, most farmers have no knowledge about it. Thus, because of the problems of communication, many farmers think that they have no alternative but to buy produce (especially during winter) to be present on the market and not to lose their regular customers. However, traceability of food, which is a key aspect of short food supply chains, becomes questionable this way (Benedek et al, 2014).

This three different types of markets should meet the same food safety requirements the only difference is the types of the products. Herman et al (2012) collected the most important foodsafety advantages of the short food supply chain. The authors emphasized that a reduced risk for the introduction of certain emerging microbiological hazards is expected for the short food supply chain production due to its in general local sourcing of inputs (raw and auxiliary materials, feed) in comparison with the globalized food production. In the short food supply chain it is more feasible to maintain a short and direct link between primary production (harvest, milking, slaughter) and subsequent need of storage until food processing and the distribution to the consumer. In general, this short time frame of storage can be considered as beneficial for the microbiological quality and safety of the end product. In most cases, the short food supply chain limits processing to the agricultural products produced at the farm; this in contrary to most conventional processing units where raw materials of multiple producers are entering the same processing plant. It is expected that in the short food supply chain, the contamination of the processing area with a pathogen would be limited to those strains circulating on the own farm and its environment. Potential contamination sources can thus be more limited (Herman et al, 2012). These facts underpin the legitimacy of the simpler rules.

\section{The most important characteristics of the surveyed farmer}

All of the conventional farmer sell their product on farmers' market and traditional market as main marketing channels. While the organic farmers used the Biokultúra Organic market as the main marketing channels. Only with one exemption all of the conventional farmers agreed in that the hygienic rules are useful and reasonable. Only one fruit and vegetable producer should not control pesticide residues because the low level of pesticide use. The animal keeping farmers found the cost of examination unreasonable high. The farmer who thought the rules to be complicated had problems with the requirements of live animal transport in case of small quantity. He also complained on the small scale meat sale requirement, he found them 
unrealistic. The organic farmers found the rules to be acceptable and reasonable. They gave 2.1 points for the difficulty of the rules on a 1 to 5 scale. These are very good news from the aspect of food safety because in case of acceptance the producers tend to keep them. On the basis of the survey data the conventional farmers thought the consumers relations as the most important characteristics of direct sale (Figure 1), while in the case of organic farmers it means in the first place higher profitability and reliable market conditions (Figure 2). The farmers could give 1 to 5 points for each statements where 1 meant "I do not agree" and 5 was "I fully agree with the statement". As we can see on the figures the organic farmers did not find the quantity so limiting factor as the conventional. Some of organic farmers added to this answer that they sometimes happy to produce enough product to bring to the weekly market, because of the special producing methods in organic farming. Most of the organic farmer feel that the risk of production is mainly influenced by the weather and other unexpected events. They usually also thought that the food safety is influenced mainly by the production requirements and not by marketing channels. However the consumers feel lower food safety risks in the case of direct producers market.

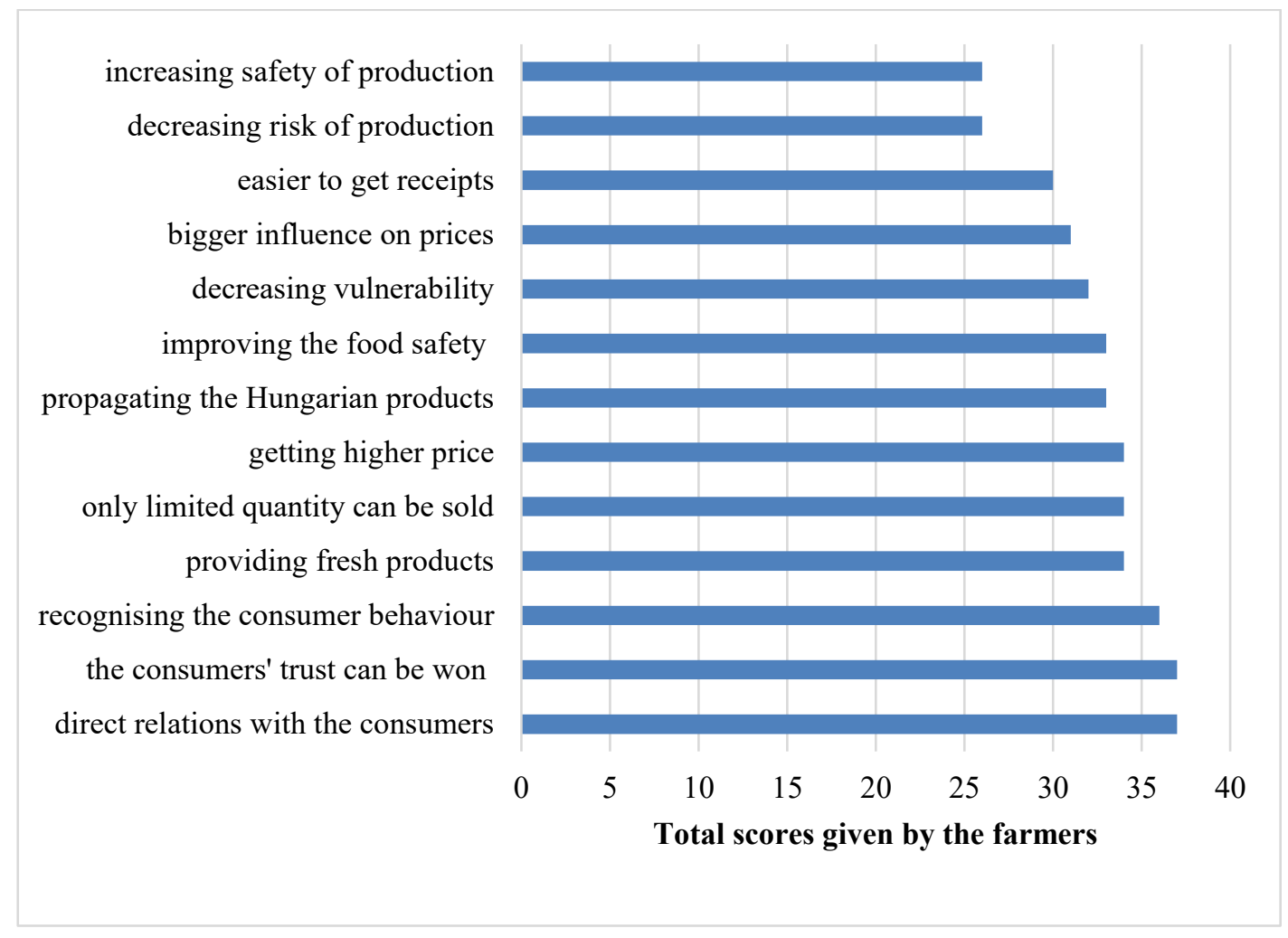

\section{Figure 1: The most important characteristics of direct sale according to the conventional farmers (2017)}

\section{Source: On the basis of own data collection}

The conventional farmers do not feel higher security of sale in the case of direct sale in general so their vulnerability cannot be decreased so much in this way. This is due to the higher competition in this form of sale as compared to the closed community of the organic producers selling on the surveyed market. 


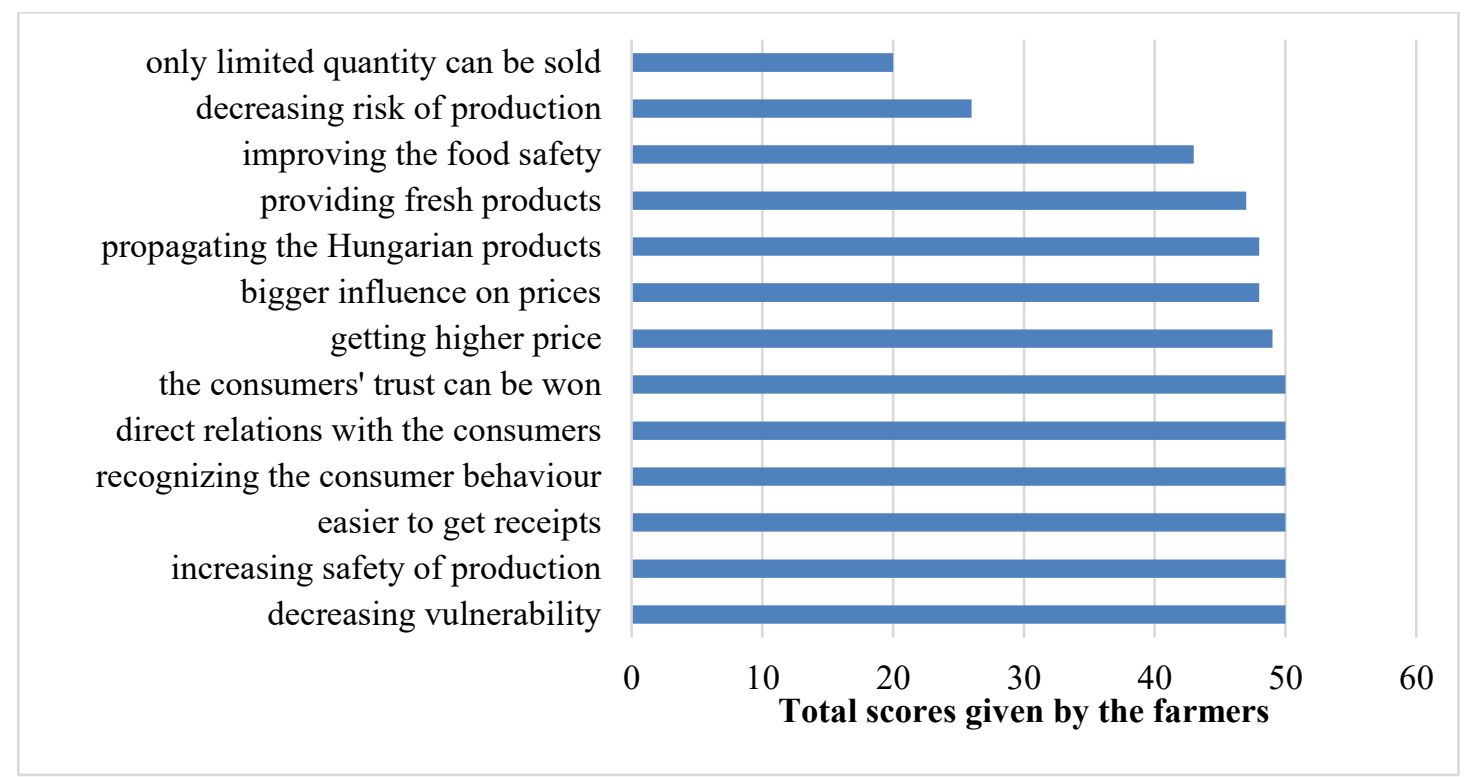

Figure 2: The most important characteristics of direct sale according to the organic farmers

\section{Source: On the basis of own data collection}

According to the study of the Hungarian Agricultural Research Institute the Hungarian legislation relating to farmers' direct sales from 2010 improved farmers' opportunities. The authors found that the main benefit of direct selling were daily income, increased profitability, direct trust relationship with the consumers, reduced dependence on the bargaining power of retailers. The main limiting factors of direct sales were geographical and social limitations on demand, demand fluctuates so it is difficult to plan. They emphasised that the legal requirements of direct sales make it investment intensive activities (Mácsai et al, 2012). The interviewed organic and conventional farmers agreed in that it is a time demanding and labour intensive activity in a great extent in accordance with the findings of the abovementioned study (Figure 3 and 4).

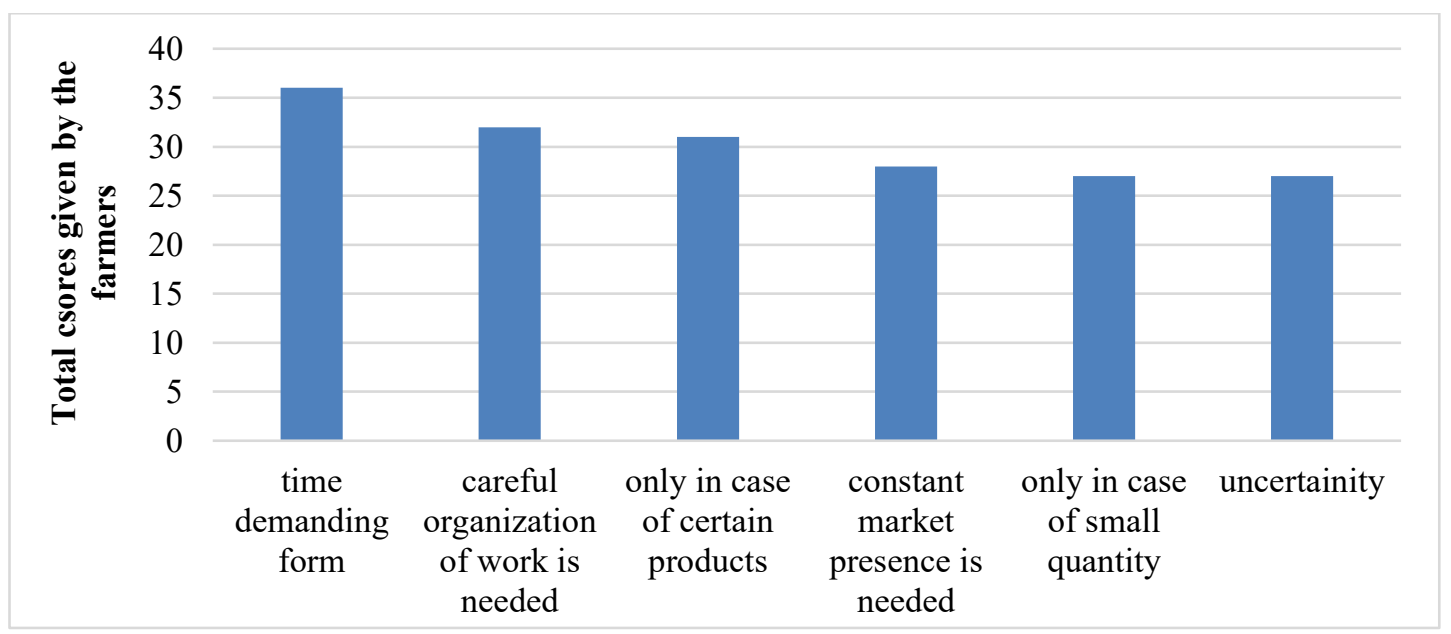

Figure 3: Those characteristics of direct selling which can mean limitations according to Source: On the basis of own data collection the conventional farmers (2017)

The characteristic "uncertainty " is not very featuring or rather limiting factor in their opinion of both categories of farmers at such marketing channel. 


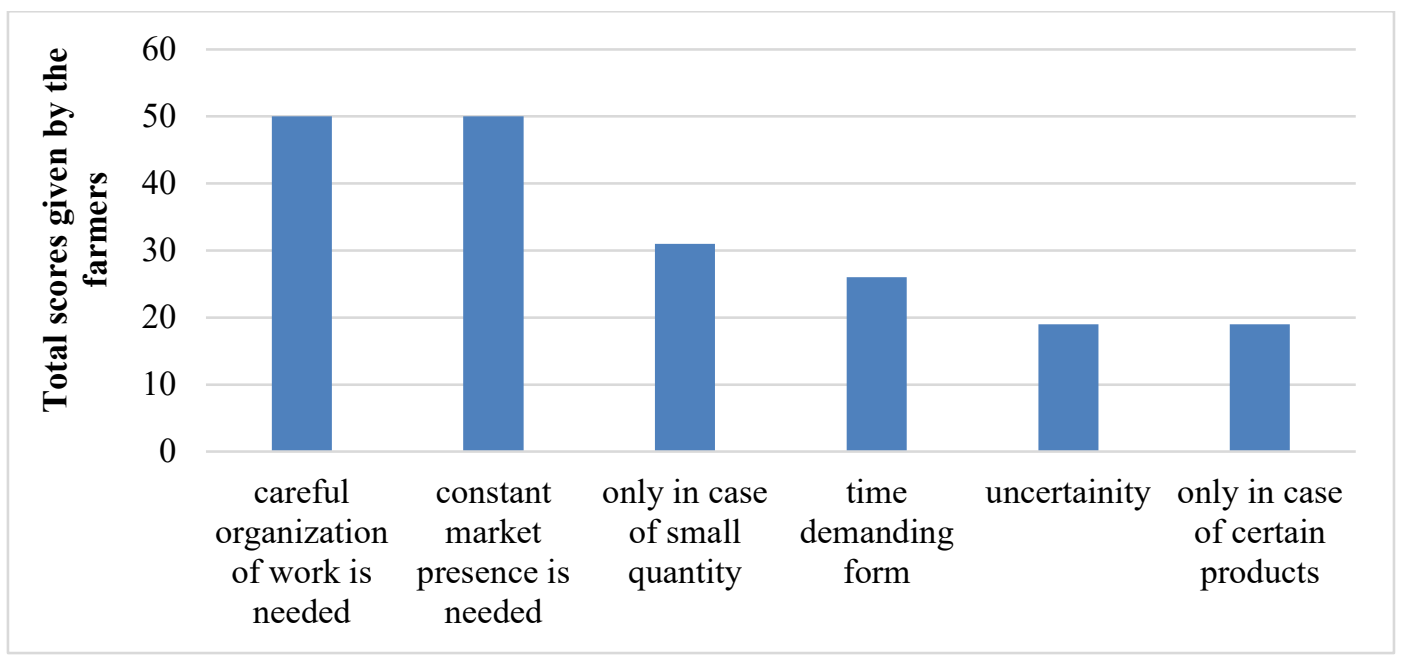

\section{Figure 4: Those characteristics of direct selling which can mean limitations according to the organic farmers (2017)} Source: On the basis of own data collection

In the case of the closed organic market the constant market presence is more important, because the consumers search for them every week.

It is important to mention that all of the organic farmers thought that the market will stagnate in the near future while most of the conventional farmers with two exemptions felt that the local food markets will develop.

\section{Conclusions}

From 2006 to 2010, in a series of amendments, the decree on small producers finally regulated all issues relating to small scale production, manufacturing, hygiene, trade, control, and certification. According to the professional literature there are three main categories. Different food safety requirements relating to these categories. Inside these categories many types of SFSCs evolved after the simplified hygienic rules for production and market. The different SFSCs have different motivation and limitations. But it can be stated that the frequent relationship with the consumers and through this the increased trust toward local food is general. According to the applied survey data it can be stated that almost all of the conventional farmers agreed in that the hygienic rules are useful and reasonable. The surveyed organic farmers also found the rules to be acceptable and reasonable. These are very good news from the aspect of food safety because in case of acceptance the producers tend to keep them. The interviewed organic and conventional farmers agreed in that direct sale is a time demanding and labour intensive activity in a great extent. Higher price as a motivating factor proved generally not to be the most important factor in making decisions. However the farmers do not feel that the food safety would improve through direct sale. It is strange because the stronger connections with the consumers improve food safety in itself, because the farmers can provide more information to the consumers. Both group of farmer considered the most important limiting factor of direct sale the organization of work.

\section{Acknowledgement}

This work was created in commission of the National University of Public Service under the priority project KÖFOP-2.1.2-VEKOP-15-2016-00001 titled "Public Service Development Establishing Good Governance" and the Cooperative Partner/Institution 


\section{References}

1. Augère-Granier, M-L. (2016): Short food supply chains and local food systems in the EU. European Parliamentary Research Service. Briefing

2. Balázs B. (2012) Local Food System Development in Hungary. International Journal of Sociology of Agriculture and Food, 19:3, 403-421.

3. Balázs, B., Bertényi, G., Králl, A., Pintér, L., Strenchock, L. (2015)::PATHWAYS project Exploring transition pathways to sustainable, low carbon societies, January 2015.

4. Benedek Zs. - Balázs B. (2014) A rövid ellátási láncok szocioökonómiai hatásai (Socioeconomic impacts of short food supply chains), Külgazdaság 2014/5-6. •

5. Benedek, Zs. - Fertö, I.- Baráth, L. - Tóth, J. (2014): Differences of small-scale farmers and the related short agri-food value chains. An empirical evidence from Hungary Mühelytanulmányok, MTA, 2014

6. Cowell, J., S. Parkinson, S. (2003): Agriculture, Ecosystems and Environment 94 (2003) 221-236p.

7. Hámori, J.(2013): Az etnocentrizmus érvényesülése a fogyasztói döntéseknél az élelmiszerek piacán, PhD Értekezés, Gödöllő, 2013

8. Herman, L.- Heyndrickx, M. - De Reu1, K. - Van Coillie, E. - Uyttendaele, M. (2012): Microbiological safety and quality aspects in relation to the short food supply chain. Food Safety of Short Food Supply Chain, Symposium SciCom 2012.

9. Jakopánecz, E. (2015): Élelmiszer-vásárlási tudatosság és fogyasztói ellenállásra való hajlandóság a magyar felnőtt lakosság körében. Dr. Töröcsik Marketing Inspiráció Fogyasztói Magatartás Kutató Intézet. WHO Egészség Világnap Élelmiszerbiztonság konferencia, 2015. április 7.

10. Kneafsey, M. - Venn, L. - Schmutz, U. - Balázs, B. - Trenchard, L. - Eyden - Wood, T. - Bos, E. - Sutton, G. - Blackett, M. (2013): Short Food Supply Chains and Local Food Systems in the EU. A State of Play of their Socio-Economic Characteristics. JRC, 2013

11. Mácsai, É.- Kujáni, K.- Juhász, A. szerk. - Hamza, E.- Györe, D. (2012): A közvetlen értékesítés szerepe és lehetőségei a hazai élelmiszerek piacrajutásában. Élet a modern kiskereskedelmi csatornákon kívül? AKI, 2012

12. Marsden, T. - Banks, J. - and Bristow, G. (2000) Food Supply Chain Approaches: Exploring their Role in Rural Development. Sociologia Ruralis 40 (4), 424-438.

13. Papadopoulos, N.- Butt, I. (2006): Place image and place branding: what the data tell us, Vezetéstudomány, 2006. 7-8 szám, 73-87 p.

14. Petrás, E. (2005): A lokalizáció és lokális identitás a globalizáció korában, Szociológiai Szemle 2005/4, 85-98 p.

15. Renting, H. - Marsden, T. - Banks, J. (2003) Understanding Alternative Food Networks: Exploring the Role of Short Food Supply Chains in Rural Development. Environment and Planning A 35, 393-411.

16. Szilágyi T., Boldizsár G.: (2016) A biztonságos vidék, mint az állam létfeltétele $P R O$ SCIENTIA RURALIS 1:(4) pp. 24-34.

17. Ter Kuile, B. (2012): Food safety problems specific to the short chain selected case studies from the Netherlands. Food Safety of Short Food Supply Chain, Symposium SciCom 2012.

18. Tóth, T.-Káposzta, J. (2014): Tervezési módszerek és eljárások a vidékfejlesztésben. Elmélet. SZIE Kiadó, Gödöllő, 163 p. 